\title{
The Biological Clock: Age, Risk, and the Biopolitics of Reproductive Time
}

\author{
Martina Yopo Díaz ${ }^{1,2}$ (D) \\ Accepted: 7 October 2020 / Published online: 31 October 2020 \\ (C) The Author(s) 2020
}

\begin{abstract}
The present article explores the social and subjective dimensions of the biological clock and its implications for reproductive time through a qualitative study based on 40 life story interviews of women from Santiago de Chile. Although the narrative of the biological clock has become a prevalent frame for addressing reproductive time in the context of late childbearing, age-related infertility, and the use of assisted reproductive technologies, few studies engage in an in-depth analysis of the biological clockits boundaries, dynamics, and the particular ways in which it shapes women's views and experiences of reproductive time. The present article aims to advance current knowledge on the intersection of time, reproduction, and biopolitics by arguing that the biological clock regulates reproductive time by shaping the boundaries and dynamics of female fertility through the clock. By determining reproductive time as quantitative, standardised, linear, and irreversible and by outlining the passing of time through pressure, risk, and burden, the biological clock determines when it is possible and desirable to have children and regulates reproduction, gender, and the female life course. These findings highlight the importance of critically addressing the narrative of the biological clock and its implications for women's views and experiences of reproductive time.
\end{abstract}

Keywords Biological clock $\cdot$ Time $\cdot$ Gender $\cdot$ Reproduction $\cdot$ Biopolitics $\cdot$ Chile

The biological clock has become a prevalent framework for addressing reproductive time in the context of late childbearing, age-related infertility, and the use of assisted reproductive technologies. In many countries, women are postponing the transition to motherhood. Several studies show that over the past decades the percentage of women who are delaying childbearing and having their first child at 35 or later has increased (Cooke et al. 2010; Lavender et al. 2015; Wagner et al. 2019; Wyndham et al. 2012). Among others, Billari et al. (2011, p. 616) argue that this has been "one of the most important changes in reproductive behaviour in recent decades." This transformation is prevalent in high-income Western

Electronic supplementary material The online version of this article (https://doi.org/10.1007/s11199-020-01198-y) contains supplementary material, which is available to authorized users.

Martina Yopo Díaz

miy21@cam.ac.uk

1 Department of Sociology, University of Cambridge, Cambridge, UK

2 Max-Weber-Institut für Soziologie, University of Heidelberg, Bergheimer Str. 58, 69115 Heidelberg, Germany developed countries and is also emerging in middle-income developing countries (Beets et al. 2011).

Postponing the transition to motherhood imposes challenges to reproductive time because the time required to achieve personal and social milestones conflicts with the available time for childbearing determined by female fertility. As Martin (2017, p. 97) argues: “women's capacity to conceive may decline before they feel socially or emotionally competent to have a child" and "when women feel socially and emotionally prepared to have a child, they may no longer be in the optimal biological range to have a child." Various scholars have noted this conflicting character between biological and social "clocks" (Billari et al. 2011; Daly and Bewley 2013; Martin 2017; Perrier 2013), as well as the problematic character of the biological clock in women's reproductive experiences (Daly and Bewley 2013; Friese et al. 2006; Lavender et al. 2015; Martin 2017).

Challenging the biological clock by delaying childbearing involves managing multiple risks regarding fertility, the development and outcome of pregnancy, the health of mother and child, and women's ability to take care of their children and be "good" mothers. Several studies assert that challenging 
the biological clock involves risks such as infertility, miscarriage, preterm delivery, placenta previa, caesarean section, prolonged labour, preeclampsia, hypertension, gestational diabetes, maternal mortality, low birth weights, increased perinatal morbidity, chromosomal abnormalities, and congenital malformations, among others (Billari et al. 2011; Cooke et al. 2010; Daly and Bewley 2013; Macintosh 2015; Wyndham et al. 2012). Challenging the biological clock by delaying childbearing is also associated with risks to women's ability to nurture and raise children. Scholarly work on late fertility has documented the ways in which "old" age is often associated with a higher likelihood of experiencing illness, medical problems, and lack of energy (Martin 2017; Settersten and Hägestad 1996; Settersten Jr and Mayer 1997) and is perceived as a liability for good mothering (Chen and Landau 2015; Settersten and Hägestad 1996).

Analysing the narrative of the biological clock is important because it affects not only women's views and experiences regarding fertility and childbearing, but also their dispositions and practices regarding sexuality, family formation, educational and professional careers, and the use of assisted reproductive technologies. Previous scholarly work has shown that women's awareness of the biological clock affects their behaviour regarding sexual intercourse (Easton et al. 2010), long-term partners and union formation (Moss and Maner 2014; Wagner et al. 2019), postgraduate education and the labour market (McAlister 2008), and the use of donor oocytes (Friese et al. 2006) and egg freezing (Baldwin et al. 2019; Brown and Patrick 2018; Martin 2010). From this perspective, accounting for the narrative of the biological clock provides valuable insights to understand how women engage with reproduction and structure different life course trajectories.

The present article examines the narrative of the biological clock and the particular ways in which it shapes women's views and experiences of reproductive time through the analysis of 40 life story interviews conducted with women from Santiago de Chile. The aim of my article is not to account for the time constraints of female fertility and risks of delaying childbearing, but rather to explore how they are understood and lived by women through the narrative of the biological clock. Although there is a growing number of studies referring to the biological clock, little is known about what it is, how it works, and the particular ways in which it shapes reproductive time. Drawing on theoretical insights on social time (Adam 1995, 2006; Zerubavel 1985) and biopolitics (Foucault 1978, 2003; Rose 2007), the present article makes a unique contribution to this field of research by addressing time as a fundamental dimension of contemporary biopolitics of reproduction and engaging in an in-depth empirical analysis of the biological clock itself - its boundaries, dynamics, and the particular ways in which it shapes women's views and experiences of reproductive time.

\section{Deconstructing the Biological Clock}

In social sciences, scholarly work on the biological clock has increased significantly in the past two decades as a way of addressing the problem of fertility decline and the risks of ageing in the context of late motherhood and the use of assisted reproductive technologies (Beaujouan and Solaz 2013; Easton et al. 2010; Keeney and Vernik 2007; Lavender et al. 2015; Macintosh 2015; Martin 2010; Mohapatra 2014). Despite its prevalence, the analysis of the biological clock in most studies is constrained to its use in expressions to characterise experiences of reproductive time, such as the ticking of the biological clock (McAlister 2008, p. 218), the problem of the biological clock (Keeney and Vernik 2007, p. 114), the pressure of the biological clock (Mohapatra 2014 , p. 390), the struggle against the biological clock (Beaujouan and Solaz 2013, p. 63), and snoozing the biological clock (Cooke et al. 2010, p. 1325). Some studies also describe the biological clock as the limited period of time between puberty and menopause during which women are able to conceive children (Moss and Maner 2014; Wagner et al. 2019) and the feelings of pressure and anxiety that arise from acknowledging the finite character of biological reproduction (Brown and Patrick 2018; Lahad 2012; Martin 2017). Only few studies go further and characterise the biological clock as a social construction that regulates reproductive time and gender roles (Amir 2006; Friese et al. 2006). Overall, this background reveals that there is little knowledge on the biological clock itself - its boundaries, dynamics, and the particular ways in which it shapes women's views and experiences of reproductive time - and that the social and subjective implications of making sense of the boundaries and dynamics of female fertility through clock time remain largely unexplored.

The fact that female fertility is subject to time constraints has long been acknowledged, but it has been only a couple of decades since this understanding started being interpreted through the biological clock. The narrative of the biological clock emerged in the late 1970s and early 1980s to address the tensions between the social and biological dimensions of reproductive time in the context of women's participation in the labour force, demographic shifts toward delayed childbearing, and the emergence of assisted reproductive technologies (Friese et al. 2006). Around this time, the narrative of the biological clock as a metaphor of female fertility started making its way into mainstream press and publications. Representative of this trend is the book Up Against the Clock: Career Women Speak Out on the New Choice of Motherhood (Fabe and Wikler 1979), which addresses how professional women in their late thirties negotiate whether and when to have children as they attempt to reconcile the conflicting demands of work and family life. From its emergence, the narrative of the biological clock has been structured upon normative conceptions of gender, 
reproductive time, and the female life course. As Amir (2006) argues, the biological clock is a mechanism that control forms of living regarding reproduction, heteronormativity, and family formation through the normative regulation of time.

\section{Clock Time as Biopolitics}

I draw on Foucauldian and post-Foucauldian approaches to biopolitics as a theoretical framework to address the ways in which the narrative of the biological clock shapes women's views and experiences of reproductive time. Foucault (2003, p. 247) outlines biopolitics as a new technology of power that emerges to control "men insofar as they are living beings." This politics of life means that biological processes like health, birth-rates, and life expectancy become the focus of governmental practice. "It is, in a word, a matter of taking control of life and the biological processes of man-as-species" (Foucault 2003, pp. 246-7). The regularisation of reproduction is at the core of the governing of life. Foucault (2003, p. 243) argues that the rate of reproduction and the fertility of the population "become biopolitics' first objects of knowledge and the targets it seeks to control." It is through techniques like the socialisation of procreative behaviour (Foucault 1978) and the prescription of compulsory birth-control (Foucault 2003), that governments seek to regularise social reproduction.

Post-Foucauldian approaches reveal that contemporary biopolitics are being reshaped by notions of choice and risk. Rose (2001, p. 1) argues that new configurations of power and control have taken shape, structuring contemporary biopolitics as "risk politics." In an age of choice and individual responsibility, the body, its capacities, the minimisation of health risks, and the optimisation of future vitality become the focus of governmental power (Rose 2007). Several feminist scholars have drawn on Foucauldian and postFoucauldian approaches to address contemporary biopolitics regarding reproduction. For Whittaker (2015), the advent of contraceptives, synthetic hormones, assisted reproductive technologies, and genomic technologies enables the control of human fertility and thus the emergence of neoliberal governmentalities over women's bodies and life politics. Similarly, Waldby and Cooper (2008) assert that women's reproductive biology becomes the focus of extensive biomedical research, global commercial innovation, and state policy interventions. For them, policies to reverse the decline of birth rates and delay of first childbearing, such as improved childcare, better maternity leave, baby bonuses, and the exhortation of women to have more children, exemplify the ways in which states enact contemporary biopolitics regarding reproduction and female fertility.

Foucault (1978, p. 136) characterises technologies of power as "essentially a right of seizure: of things, time, bodies, and ultimately life itself." Social theory has extensively outlined time as a symbolic tool of social control (Adam 1990, 2006; Elias 1989; Zerubavel 1985). Time enables regulation of the population by setting social calendars and strict boundaries to the timing of life course events (Elder Jr 1975; Settersten Jr 2003). Clock time is not time itself but rather a social construction that emerged in Europe during the late medieval period and became hegemonic through capitalism (Martineau 2015). Since then, it has become "a social and economic reality that structures, controls, disciplines, and provides norms for our social life" (Adam 1990, p. 120). Through the clock, time became standardised, neutral, and disembedded from the rhythms of the body and nature (Adam 1990, 2006). As a mechanism of social regularisation, "clock time is used to regulate and rationalise the pace and seasonality of organisms and beings" (Adam 2006, p. 115).

Gender and feminist scholars have rightfully criticised the prevalence of the clock to account for women's experience of time. Bryson (2007), Hughes (2002), and Leccardi (1996) argue that the linear, objective, divisible, and abstract time in patriarchal capitalist societies neglects the multiple, cyclical, relational, and fragmented nature of reproductive, domestic, and care time. These critiques also extend to prevalent ideas of time regarding childbirth and mothering. Adam (1995, p. 49) describes time during delivery as "oscillating between two times - the archetypal and endogenous temporality of the birthing process and the rational time of obstetrics." Similarly, Bartlett (2012, p. 127) asserts that in negotiating breastfeeding within the demands of paid work, it seems that "breastfeeding time runs counter to institutional time, business time, corporate time." These critiques suggest that clock time is not only different but also competing and in tension with women's experiences of reproductive time.

\section{The Chilean Context}

The great majority of studies on the biological clock have been conducted in North America and Europe, but the delaying of childbearing and the tensions between the social and biological dimensions of reproductive time are not exclusive to these countries. Chile represents an interesting case to analyse the narrative of the biological clock beyond Western developed countries and contribute to bridge the gap of knowledge of contemporary reproductive time at a global level. In contemporary Chile, the prevalence of cultural norms that conflate womanhood and motherhood and naturalise childbearing in the female life course (Montecino 2018; Valdés 2007; Yopo Díaz 2020) coexist with an increasing participation of women in tertiary education and the labour market (Larrañaga 2007; The World Bank 2019). As elsewhere, these changes have restructured fertility and reproductive patterns. Studies conducted in the last decade reveal that 
an increasing number of women are delaying first childbearing and becoming mothers at an older age (Cerda 2010; Fuentes et al. 2010; Yopo Díaz 2018a, 2018b). Data from Instituto Nacional de Estadísticas (2017) reveals that women's average age at first childbearing has increased almost 3 years in the last decades from 22.47 years in 1972 to 25.04 years in 2016. The use of assisted reproductive technologies in Chile is rapidly increasing, from 90 cycles per million women in fertile age in 1990 to 634 in 2013, but remains constrained by its financial costs (Velarde 2016) and prevalent religious beliefs regarding the nature of reproduction (Herrera et al. 2013). Although adoption is available, it is not always considered an alternative due to the symbolic value of blood, biology, and genetics in cultural ideas of parenting in Chile (Herrera 2011).

The narrative of the biological clock has become prevalent to address the problem of fertility decline and the risks of ageing in the context of late childbearing in contemporary Chile. In 2015, the Chilean newspaper El Mercurio published an article in which Dr. Pommer, former president of the Chilean Society of Reproductive Medicine, explained age related infertility and the risks of delaying childbearing. In this article, Dr. Pommer (2015, para. 1) argued that "the woman has a biological clock of the ovules that determines her possibility of being mother." He further commented that "this biological clock acts as a sword of Damocles, because although the quality of the egg starts decreasing from the age of 20 , it is from the age of 35 that this decrease is radically accentuated" (Pommer 2015, para. 2). This article exemplifies the prevalence of the biological clock in mainstream press (Aburto Prieto 2016; El Mercurio 2017; El Mostrador 2017; Hirane 2017) as well as in the narrative of doctors, health professionals, and medical institutions (Clínica Alemana 2012; Clínica Las Condes 2017; Manzur 2014; Meier Furst 2018). Often depicted through the image of a woman with a clock in her hands or a pregnant woman with her hands on her stomach, in contemporary Chile the biological clock is commonly used to refer to the time constraints of female fertility, age related infertility, the risks of delaying childbearing, and the advantages of assisted reproductive technologies.

\section{The Present Study}

In the present article, I draw on the intersection of time, reproduction, and biopolitics to examine the particular ways in which the narrative of the biological clock shapes women's views and experiences of reproductive time. Using accounts from life story interviews conducted with women from Santiago de Chile, I examine how the narrative of the biological clock outlines the boundaries and dynamics of reproductive time, the meanings of age and ageing, the role of risk and agency in timing childbearing, and reproductive inequalities between men and women. In doing so, I stress time as an essential dimension of contemporary biopolitics of reproduction and address the particular ways in which the narrative of the biological clock regulates gender and reproduction by determining when women should have children.

\section{Method}

\section{Research Design}

In the present article I draw on the findings of a qualitative study on the timing of the transition to motherhood in contemporary Chile. My study was reviewed and approved by the Ethics Committee of the Department of Sociology, University of Cambridge. I used a qualitative research design because my intention was to "study things in their natural setting, attempting to make sense of, or interpret, phenomena in terms of the meaning people bring to them" (Denzin and Lincoln 2005, p. 3). Much has been said about reproductive time, but only few approaches have taken women's own voices and experiences into account to understand it. I follow Miller (2007, pp. 337-338) in introducing an epistemological shift by focusing not on "what is being said about women" but on "what women themselves are saying." Through this approach, I aimed to gain an in-depth understanding of the particular ways in which the narrative of the biological clock shapes women's views and experiences of reproductive time.

A research strategy based on a "thick description" (Geertz 1973) of a small number of case studies is preferable for understanding complex social phenomena such as the intersection between female fertility and clock time. This approach also advances current knowledge on the biological clock given that most studies address it either from a quantitative perspective (Beaujouan and Solaz 2013; Easton et al. 2010; Keeney and Vernik 2007; Moss and Maner 2014; Wagner et al. 2019) or a literature review (Cooke et al. 2010; Macintosh 2015; Mohapatra 2014). The few studies that take on a qualitative approach do not focus on the biological clock itself but rather on egg freezing (Brown and Patrick 2018; Martin 2010), singlehood (Lahad 2012), the timing of childbearing (Lavender et al. 2015; Martin 2017), and women's narratives of age-related fertility decline (Friese et al. 2006).

\section{Participants}

The findings presented in the present article are based on the analysis of narratives of transition to motherhood of 40 women born and raised in Chile who reside in the capital city of the country, Santiago de Chile. I used stratified purposeful sampling (Flick 2009) to select women from different ages and socioeconomic status. Socioeconomic status was determined by jointly considering variables related to educational 
attainment, occupation, income, and place of residence as well as women's self-positioning within the class structure of Chilean society. The participants are lower $(n=12)$, middle $(n=16)$, and upper $(n=12)$ class and aged between 18 and 30 $(n=10), 31-45(n=10), 46-60(n=11)$, and 61-75 $(n=9)$. Most of them were mothers $(n=28)$ but some were not $(n=$ 12). In comparison to women in the subsample of mothers, women in the subsample of non-mothers were younger, mostly in their 20s and 30s, and single; some had partners but only one was married.

In the present study I selected women who had children and women who did not because reproduction is firmly grounded within femininity so that all women are constrained into negotiating fertility and childbearing (Sevón 2005). Furthermore, by including participants who do not have children, I address the experiences of those women who enact reproductive time by delaying childbearing or remining childless. The participants were contacted through key informants using a snowball sampling method. All agreed to participate in the research and signed informed consents. In the present article, the names of the participants are replaced by pseudonyms to support confidentiality.

\section{Data Production}

Two semi-structured life story interviews were conducted with each of the participants. Life story interviewing is a qualitative research method for gathering information on the subjective essence of the life of an individual through biographical narratives (Atkinson 2002). The first interview addressed the women's life stories and the second interview focused on their experiences with the transition to motherhood. In the second interview, all participants were asked general questions regarding reproductive time (e.g., "At what age did you have or would like to have your first child?"; "Why is the age at first childbearing important?"; "At what age should women have their first child?"; "What are the age limits for first childbearing?"; "What are your thoughts on the delay of childbearing?") as well as specific questions regarding the biological clock (e.g., "Some people say that women have a biological clock. Have you heard that before?"; "If yes, where and from whom?"; "What does it mean?"; "What do you think about it?"). (For the full list of questions, refer to the online supplement.) In some of the interviews, the biological clock emerged spontaneously as a means of addressing reproductive time. All women who mentioned the clock spontaneously were middle- and upper-class, had at least a college degree, and either became mothers after 30 or didn't have children. When it did not, I asked women if they had heard of the biological clock and encouraged them to describe what they knew and thought about it. Some of participants, mainly older and lower-class women, claimed not having heard about the biological clock or not knowing what it was. The interviews were conducted in Spanish between September 2016 and May 2017 and took place mostly in the house or workplace of the interviewees.

\section{Data Analysis}

I recorded the interviews using digital recorders and transcribed them using a verbatim method. The audio files range from 39 to $130 \mathrm{~min}$ and have a mean duration of $72 \mathrm{~min}$. The interviews were analysed vertically and horizontally through qualitative content analysis (Schreier 2014) and coded using ATLAS.ti 8. Using this software saved time in processing the information, simplified the administration of texts and codes, and provided rigour to the data analysis by facilitating consistency in the organisation, selection, and presentation of the empirical material. The coding process was dynamic and creative, moving "quickly back and forth between types of coding, using analytic techniques and procedures freely and in response to the analytic task" (Strauss and Corbin 1998, p. 58). I used a flexible version of open, axial, and selective coding (Flick 2009) to categorise and organise the empirical data from the interviews. In analysing the interviews, I went through the transcriptions and coded words, sentences, and paragraphs through constructed and in vivo codes (Flick 2009).

Sampling decisions in the research process take place not only when selecting participants but also when analysing the empirical material and presenting the findings (Flick 2009). All the interviews were analysed for the present article, but the findings are based mainly on the narratives of younger middle- and upper-class women because the biological clock was more significant in their views and experiences of reproductive time. This focus is consistent with the findings of Friese et al. (2006) and Martin (2017), who suggest that the narrative of the biological clock is prevalent in the reproductive experiences of middle- and upper-class, educated, and professional women because they have a higher likelihood of delaying first childbearing and becoming mothers later in life.

\section{Results}

The findings of the narrative of the biological clock and the particular ways in which it shapes women's views and experiences of reproductive time are presented in this section. First, I examine how the narrative of the biological clock shapes the boundaries of reproductive time, the meanings of age and ageing, and when it is possible and desirable to have children. Second, I discuss how this narrative outlines time as linear, progressive, and irreversible, determining the passing of time and the future through risk and uncertainty. Third, I analyse how the narrative of the biological clock shapes a sense of agency in which women are expected to keep track of time, rationally assess the risks of ageing, and enact responsibility in 
timing childbearing. Finally, I explore how this narrative reinforces traditional gender norms and reproductive inequalities between men and women. To contextualise these findings, a detailed sociodemographic characterisation of the participants is presented in Table 1 and a detailed description of emergent themes regarding the narrative of the biological clock is presented in Table 2. Where relevant, I report the number of children a quoted woman has in parentheses.

\section{Age and the Boundaries of Reproductive Time}

In the interviews I conducted, the women often make sense of the biological clock as a limited period of time that circumscribes their capacity to have children. For Adela (0), the biological clock refers to "that constrained capacity to have children only until a certain age." For her, reproductive time is perceived and lived as constrained; it is finite and has an ending. As Friese et al. (2006, p. 1551) have pointed out, for women, the biological clock is a "kind of deadline as they made decisions about childbearing." This is the case of Paula (1). She believes that the biological clock determines when women can become mothers:

I think that it is linked, it is linked to motherhood. It is until you get the menopause and then you no longer have your period. Then you no longer ovulate, you have no more eggs, you no longer have the possibility of being a mother. (Paula)

The narratives of the biological clock that I analysed reveal the cultural belief that the limits of reproductive time are rooted in the fertility of the female body. For Laura (3), "the biological clock is the time of life in which women are fertile." This narrative embodies reproductive time in female fertility and its limits are within the time period between menstruation and menopause, a notion that is reflected in other studies (Friese et al. 2006; Keeney and Vernik 2007; Moss and Maner 2014; Wagner et al. 2019). This embodiment of the limits of reproductive time in female fertility through the biological clock is also reflected in the narrative of Olivia (0):

From the time you get your period at 13 until you get the menopause at 42,43 , that is the time when you can have children. That would be the biological clock, the time in which you are fertile. (Olivia)

These embodied perceptions reveal that the narrative of the biological clock shapes reproductive time as constrained; having children is not possible "at any time." From this perspective, reproductive time is a limited quantity; it "runs out" and "less" of it is left as time passes by. This constraint is reflected in the reproductive experience of Beatriz (2). In discussing her transition to motherhood, she argues: "I felt that I was running out of time. It was like 'ten, nine, eight, seven, six,' like that." Similar studies have also noted the way in which the narrative of the biological clock time shapes reproductive experiences through the feeling of "running out of time" (Baldwin et al. 2019; Easton et al. 2010; Martin 2017; Wagner et al. 2019).

The narrative of the biological clock also standardises the duration and constraints of reproductive time. The clock provides this base for standardisation by imprinting a uniform, empty, neutral, and de-contextualised character to time (Adam 2006). With very few exceptions, my interviewees refer to 35 as the age in which female fertility declines and 40 as the age in which it approaches its end. Other studies have also suggested that these ages act as "magic numbers" that shape women's understanding of the time limits to experience childbearing (Brown and Patrick 2018; Martin 2017).

These standardised age "deadlines" are revealed in the narrative of Amalia (2). In discussing the limits of reproductive time, she asserts, "because all the gynaecologists say that it has to be before 35: 'If you don't want to have problems to get pregnant, it has to be before 35.' They all say the same." These standardised age "deadlines" are also relevant in Victoria's (2) understanding of the time limits of childbearing. As she argues: "it's said that after 40 women reach menopause and can no longer have children."

The narrative of Amalia (2) also reveals that the knowledge of many women about the dynamics and boundaries of reproductive time comes from medical experts. Medical knowledge and practice are known to constitute technologies of power (Foucault 2003; Rose 2007). As Foucault (2003, p. 252) has argued: "medicine is a power-knowledge that can be applied to both the body and the population, both the organism and biological processes, and it will therefore have both disciplinary effects and regulatory effects." By prescribing the limits of reproductive time through the standardised age "deadlines" of the biological clock, medical experts contribute to regulating when it is possible and desirable to have children.

Scholarly work on female fertility provides a counterpoint to the standardisation of time outlined by the narrative of the biological clock. Leader (2006) suggests that the relationship between fertility decline and age is variable because the decreased rate of the number and quality of eggs is uncertain and subject to individual variations. For Billari et al. (2011), the fact that fertility age limits are expressed through multiples of 5 and 10 is influenced by the research standards used in the field of medicine, human reproduction, and fertility. For them, the prevalence of these age limits is interesting given that "there is evidence that for obstetric outcomes, increasing age is a continuum rather than a threshold effect" (Billari et al. 2011, p. 617). Drawing on these approaches, I argue that the narrative of the biological clock embodies reproductive time within female fertility and shapes its boundaries through standardised thresholds that are socially constructed but are nonetheless perceived as natural and experienced as universal and inherent to women. 
Table 1 Characteristics of the participants

\begin{tabular}{|c|c|c|c|c|c|c|}
\hline Pseudonym & Age & Socioeconomic Status & Education & Occupation & Children & Biological clock \\
\hline Adela & 34 & Middle & Tertiary & Lawyer & 0 & $\mathrm{Yes}^{\mathrm{a}}$ \\
\hline Alicia & 72 & Middle & Secondary & Secretary & 1 & Yes \\
\hline Amalia & 40 & Middle & Postgraduate & Lawyer & 2 & Yes \\
\hline Ana & 49 & Lower & Primary & Domestic worker & 1 & No \\
\hline Antonia & 18 & Lower & Primary & Student & 0 & No \\
\hline Beatriz & 54 & Middle & Tertiary & Housewife & 2 & $\mathrm{Yes}^{\mathrm{a}}$ \\
\hline Blanca & 22 & Lower & Secondary & Student & 0 & Yes \\
\hline Carmen & 28 & Middle & Postgraduate & Sociologist & 0 & $\mathrm{Yes}^{\mathrm{a}}$ \\
\hline Cecilia & 63 & Lower & Primary & Domestic worker & 1 & No \\
\hline Consuelo & 30 & Middle & Tertiary & Lawyer & 0 & Yes \\
\hline Diana & 73 & Upper & Tertiary & Housewife & 3 & Yes \\
\hline Dominga & 41 & Upper & Postgraduate & Journalist & 1 & Yes $^{\mathrm{a}}$ \\
\hline Elena & 47 & Upper & Tertiary & Psychologist & 3 & $\mathrm{Yes}^{\mathrm{a}}$ \\
\hline Elisa & 21 & Lower & Secondary & Student & 0 & Yes \\
\hline Ester & 45 & Lower & Primary & Saleswoman & 2 & No \\
\hline Flora & 58 & Middle & Secondary & Therapist & 5 & Yes \\
\hline Gracia & 55 & Upper & Postgraduate & Historian & 2 & Yes \\
\hline Ignacia & 28 & Upper & Tertiary & Doctor & 0 & Yes \\
\hline Irene & 64 & Lower & Primary & Domestic worker & 2 & No \\
\hline Jacinta & 18 & Upper & Secondary & Student & 0 & Yes \\
\hline Laura & 39 & Upper & Tertiary & Doctor & 3 & Yes \\
\hline Loreto & 57 & Upper & Postgraduate & Teacher & 4 & Yes \\
\hline Lucía & 58 & Middle & Tertiary & Doctor & 4 & Yes \\
\hline Luisa & 61 & Lower & Secondary & Cleaning worker & 2 & Yes \\
\hline Luz & 62 & Upper & Secondary & Housewife & 11 & Yes \\
\hline Maite & 20 & Middle & Secondary & Student & 0 & No \\
\hline Manuela & 36 & Lower & Primary & Construction worker & 3 & No \\
\hline María & 74 & Middle & Primary & Domestic worker & 3 & No \\
\hline Matilde & 26 & Middle & Tertiary & Dentist & 0 & Yes \\
\hline Olivia & 29 & Upper & Tertiary & Chemist & 0 & Yes \\
\hline Paloma & 48 & Lower & Primary & Domestic worker & 3 & Yes \\
\hline Paula & 44 & Middle & Secondary & Secretary & 1 & Yes \\
\hline Rafaela & 64 & Middle & Secondary & Domestic worker & 3 & No \\
\hline Rebeca & 39 & Lower & Primary & Housewife & 2 & No \\
\hline Rosa & 59 & Middle & Primary & Merchant & 5 & Yes \\
\hline Silvia & 73 & Middle & Tertiary & Medical technician & 3 & No \\
\hline Soledad & 37 & Upper & Tertiary & Journalist & 2 & Yes \\
\hline Susana & 55 & Upper & Tertiary & Teacher & 2 & Yes \\
\hline Victoria & 49 & Lower & Primary & Domestic worker & 2 & No \\
\hline Violeta & 38 & Middle & Tertiary & Social worker & 0 & Yes \\
\hline
\end{tabular}

Note. Biological clock $=$ Yes, if the participant had heard of the biological clock and knew what it was

${ }^{a}$ Mention of the biological clock emerged spontaneously as a means of addressing reproductive time

\section{Risk and the Dynamics of Reproductive Time}

The narrative of the biological clock imprints a particular rhythm to the passing of time. In the interviews, the women perceive and experience it as something linear, progressive, and irreversible. For them, time is a force that cannot be stopped or reversed. As it moves forward, it reduces women's capacity to experience childbearing. This understanding 
Table 2 Emerging themes on the biological clock

\begin{tabular}{|c|c|c|}
\hline Theme & Description & Example \\
\hline $\begin{array}{l}\text { Age and the } \\
\text { Boundaries of } \\
\text { Reproductive } \\
\text { Time }\end{array}$ & $\begin{array}{l}\text { Participants' definition of the biological clock as the limited } \\
\text { period of time in which women are fertile and that } \\
\text { circumscribes their capacity to have children. }\end{array}$ & $\begin{array}{l}\text { "This capacity of being a mother without risks that ends like } \\
\text { 'tick, tock,' 'tick, tock.' Until maybe } 36,37,40 \text {, because after } \\
\text { that maybe you don't have the biological capacity of doing it, } \\
\text { and if you can it's with a lot more risks. That's why it has a } \\
\text { certain time. It's limited." (Matilde) }\end{array}$ \\
\hline $\begin{array}{l}\text { Risk and the } \\
\text { Dynamics of } \\
\text { Reproductive } \\
\text { Time }\end{array}$ & $\begin{array}{l}\text { Participants' understanding of reproductive time through the } \\
\text { biological clock as linear, progressive, and irreversible. Time } \\
\text { as a force that cannot be stopped or reversed, which imprints } \\
\text { a sense of scarcity and urgency to reproductive time. }\end{array}$ & $\begin{array}{l}\text { "The biological clock is the period of your first menstruation, } \\
12,13,14 \text {, then your body is prepared for motherhood. But } \\
\text { that period lasts between } 30 \text {, depending on the woman, } 30 \text {, } \\
40,45 \text { years. And then no more, there is no turning back. } \\
\text { Then the clock stops, there is no turning back." (Paloma) }\end{array}$ \\
\hline $\begin{array}{l}\text { Agency and the } \\
\text { Making of } \\
\text { Reproductive } \\
\text { Time }\end{array}$ & $\begin{array}{l}\text { Participant's views and practices that the biological clock } \\
\text { involves keeping track of time, calculating age, rationally } \\
\text { assessing the risks of ageing, planning their future fertility, } \\
\text { and taking action to allocate childbearing at the "right time." }\end{array}$ & $\begin{array}{l}\text { "You have to start, in general, all my friends already start } \\
\text { around } 30 \text { to ask themselves, 'Well, is this going to be for me } \\
\text { or not? Do I want it or not? And if I want it, in what way? } \\
\text { And more or less, at what age?' Because you can't stay with a } \\
\text { question mark until you are too old, because it might be that } \\
\text { 'oh, yes, I want to,' and you can't." (Adela) }\end{array}$ \\
\hline $\begin{array}{l}\text { Gender and the } \\
\text { Inequalities of } \\
\text { Reproductive } \\
\text { Time }\end{array}$ & $\begin{array}{l}\text { Participants' perceptions that the biological clock dictates the } \\
\text { time to have children and creates a distinction and inequality } \\
\text { between men and women regarding reproductive time. }\end{array}$ & $\begin{array}{l}\text { "I find it very unfair that women have that biological clock, that } \\
\text { limited capacity to have children only until a certain age. A } \\
\text { man can become a father at whatever age he wants. It is a bit } \\
\text { unfair that biological and natural discrimination." (Adela) }\end{array}$ \\
\hline
\end{tabular}

imprints a sense of scarcity and urgency to reproductive time. This linear character of female fertility is not "natural" but rather imposed upon individual experience through the narrative of the biological clock. As Adam (1990) has argued, the linearity and unidirectionality of time derives from the prevalence of the clock as a tool for social coordination.

When discussing when it is possible to have children, the women I interviewed often resorted to the metaphor of "missing the train." Lahad (2012) also notes that this expression is used to refer to the passing of time in the context of reproduction. In discussing the time limits of childbearing, Adela (0) says: "it comes an age when everyone says 'no, she missed the train, she can't have children anymore." Similarly, Susana (2) recalls that people used to tell her that "she was going to miss the train" because she had her first child later than most women her age:

I had my first daughter when I was 29 years-old and it was not normal... Of the 29 [women in my class], I think that only two had [children] after me, and all the rest had [children] before. It was strange. It was like "you are going to miss the train." (Susana)

The metaphor of "missing the train" reveals the understanding of reproductive time underlying the narrative of the biological clock. Time, symbolised by the train, is a force in motion, moving forward at a certain speed. If you are "late," the train departs without you, and once it has departed, it is no longer possible to get on board. As Paloma (3) asserts, when it comes to the biological clock, "there is no turning back."
The narrative of the biological clock outlines the passing of time as a pressing problem. Given that fertility decreases with age and that the uterus, eggs, and female body "grow old," the passing of time is shaped as an urgency in which the future is determined by risk and uncertainty. Among others, Rose (2007, p. 70) has outlined risk as central to biopolitics: "risk here denotes a family of ways of thinking and acting that involve calculations about probable futures in the present followed by interventions into the present in order to control that potential future." In the case of reproductive time, biopolitics is enacted through the management of the risks of age and ageing.

Through the narrative of the biological clock, ageing is framed as a threat for reproduction. In discussing what the biological clock is and how it works, Loreto (4) argues, "it is that eggs age. Eggs age and that's why eggs start having more problems to endure, because they are older, their cells are older. And that's the biological clock; it's a time of pregnancy." Among others, Friese et al. (2006) noted that this narrative of "old eggs" works as a marker of ageing and the risk of infertility. For my interviewees, experiencing ageing through the narrative of the biological clock is often intertwined with feelings of fear and anxiety. Referring to her reproductive experience, Dominga (1) recalls feeling afraid of ageing and burden of age:

The years start burdening you. You have a biological clock and you want to become a mother, [and it's difficult] if you are not together with a partner or with someone that you can see as the father of your children. I 
think that issue for women that are maybe my age must be a very heavy burden. (Dominga)

These views reveal the particular ways in which the narrative of the biological clock shapes women's lived experience of reproductive time. Similar subjective experiences of the biological clock have been documented elsewhere. Brown and Patrick (2018, p. 967) describe how their interviewees "panicked" when they became aware of their biological clock and the infertility risks it posed. Martin (2017, p. 95) also describes the way in which her interviewees felt "pressured" and "anxious" by the biological clock. Overall, these views demonstrate the extent to which the narrative of the biological clock produces and reproduces "cultural anxieties about aging, illness, reproduction, and risk" (Martin 2010, p. 527).

As women approach what they understand to be the end of their childbearing capacity, time seems to go by faster. Among others, Brown and Patrick (2018) and Friese et al. (2006) also suggest that passing of time seems to "speed up" for women approaching the "limit" of their fertility. Among my interviewees, this acceleration is intertwined with the "ticking" function of the biological clock, which operates as a constant reminder of the fast-approaching finitude of reproductive time. This was the experience of Beatriz (2). As she argues, "I knew that I was running out of [time]. It is like a clock against you "ten, nine, eight." The pressure of the years." These findings are consistent with those of a study conducted by Hoffnung and Williams (2013, p. 332), who argue that the biological clock starts "ticking loudly" when women get beyond their late thirties. I follow Amir (2006) in arguing that the biological clock functions as a mechanism of social regulation by sensitising women to the passing of time and its implications for their childbearing capacity.

\section{Agency and the Making of Reproductive Time}

The narrative of the biological clock shapes a particular sense of the female self. Women are expected to keep track of time, rationally assess the risks of ageing, and take action to allocate childbearing at the "right time." Within this framework, fertility and infertility are outlined as a matter of choice and individual responsibility. This emphasis on freedom, choice, and responsibility is consistent with neoliberal governmentality (Foucault 2008). In exploring the intersection between neoliberal governmentality and biopolitics in the field of health, Rose (2007, p. 154) argues that individuals today are required "to undergo perpetual assessment" that involves monitoring health and managing risks. Similarly, Clarke et al. (2003) assert that optimising one's health is becoming an individual's moral responsibility to be fulfilled through access to knowledge, self-surveillance, prevention, and risk assessment.
In the interviews that I conducted, enacting reproduction through the narrative of the biological clock often involves being aware of time and its passing as well as of the risks and constraints that different ages pose to female fertility. As Flora (5) argues: "the woman that wants to be a mother, that's considering motherhood, has to take a look at the clock." This awareness often involves engaging in a mathematical calculation through which women assess how much time they have left to have children. For Susana (2), this calculation works in the following way:

At 35 you start calculating, ok, and if I have been [taking the pill] for all these years? And if I don't get pregnant right away? And if I've been taking the pill for many years then I wouldn't have [a child] immediately? And then if I want at 35 , but it doesn't really work until I am $36,37,38$ ? Ok, at 38 I have one, and if I want to have another? Then, ok, at 38 , at 40 . Will I be able to at 40 ? (Susana)

"Tracking" and "calculating" are strategies that women often use to manage their biological clock. This expected agency over reproductive time also involves planning and anticipating the future. Other studies have also documented the ways in which contemporary reproductive time is shaped by the expectation of predicting and anticipating the future (Martin 2010; Myers 2014). Among my interviewees, this calculation often involved knowing and shaping your future fertility in the present. This practice of knowing oneself acts as a technology of power that regularises individual behaviour (Foucault 1986). My interviewees narrate that deciding if and when to have children in the years to come often involves knowing and anticipating your future self. As Matilde (0) argues:

It's a decision that you make at a certain moment, and, as with everything, you don't know if in 10 more years you are going to regret it. And probably in 10 more years you are not going to be able to [have children]. If you are, I don't know, 36, and you say 'No, I didn't have, I'm not going to continue, I'm not going to try." And then, at 46, 50, you say "Oh, I should've done it." (Matilde)

Through the narrative of the biological clock, women are constrained to think about and decide when to have children and to be responsible for the timing of childbearing. Consequently, "waiting" and "letting time pass" are shaped as irresponsible behaviour. For Olivia (0), childbearing "over 40 is irresponsible because it's something dangerous for you, and it's something dangerous for a baby. That's why I think it's irresponsible." As Lahad (2012) has pointed out, in the narrative of the biological clock, waiting takes on a negative meaning because it is associated with fears and anxieties about 
the future. From a biopolitical perspective, letting time pass represents a subversion of the regulation of reproductive time and a neglect of the mandate of caring for oneself (Foucault 1986).

\section{Gender and the Inequalities of Reproductive Time}

In the interviews I conducted, it is often mentioned that the biological clock functions as a mandate that "dictates" when women should have children and become mothers. For Consuelo (0), "your biological clock marks the time to have babies," and for Blanca (0), "the biological clock dictates the 'now' to become a mother." Like Consuelo and Blanca, many of the women in my study believed that beyond the boundaries of the biological clock it is not possible for women to become mothers. This is the view of Elisa (0): "Us women have a certain amount of eggs and it comes a certain age in which you get the menopause and you can no longer become a mother, obviously, because you are no longer ovulating."

The interviews I conducted suggest that the narrative of the biological clock regulates reproduction by reinforcing prevalent norms regarding womanhood and motherhood. By stressing that the biological clock is inherent to female nature and dictates when women should have children, womanhood and motherhood become conflated by naturalising childbearing in the female life course. Furthermore, by stressing that the female reproductive system determines women's capacity to have children, motherhood and biological reproduction also become conflated by excluding the possibility of enacting childbearing through adoption and assisted reproductive technologies. Overall, this analysis suggests that the narrative of the biological regulates reproduction in a way that reinforces traditional gender roles and structures women's lives according to them.

At the same time, the narrative of the biological clock creates a hierarchy between biological and social fertility (Martin 2017) by subsuming the role of motherhood to the childbearing capacity of the female body. In doing so, it outlines a disjuncture between the boundaries of female fertility and the fact that women may want or feel constrained to achieve milestones like having a partner, a good job, or financial security before having children (Brown and Patrick 2018; Lavender et al. 2015; Yopo Díaz 2020). This conclusion is consistent with the findings of Friese et al. (2006, p. 1551) who argue that for women, the public domain and paid labour are outlined as an "interference" to reproduction. In my interviews, women often mention that postponing motherhood is problematic because then there is not enough time left to have children. This is the view of Rafaela (3):

So "no, not yet, not yet," "I want to do this first," "I want to finish my degree first." And time passes by because when they finish their degree they want to work. Then they find a good job and "if I get pregnant, I might lose my job and it's going to be difficult to work." And so, they postpone it. "Ok, no, but next year." And it turns out that years go by, and then it's much more difficult... What is problematic? Well, then you want to have a child and it's a lot more difficult to get pregnant because you postponed it so much. (Rafaela)

The narrative of the biological clock also creates a "natural" distinction between men and women regarding reproductive time. Despite evidence which demonstrates that male fertility also decreases with age (Thacker 2004), the narrative of the biological clock outlines that whereas women's capacity to become mothers is time-constrained, men's capacity to become fathers is free from those constraints. In discussing the limits of reproductive time, the women I interviewed often refer to this gender inequality. For Loreto (4), "the man can become a father for many more years, but the woman is limited. I mean, we have a different nature." Similarly, Elena (3) argues:

Then it comes the issue that you are going to run out of time to have children. And then there is a moment in which you say "oh, I'm running out of time." That doesn't happen to men, they never run out of time. (Elena)

This perceived difference between men and women regarding reproductive time not only reproduces the belief that there is a "natural" difference between women and men, but also outlines gender inequalities that shape women's reproductive experiences. As Amir (2006, p. 52) has noted: "the biological clock constructs a crude gender differentiation between the female bodies, to which it applies, and the male bodies, which are beyond its reach." Other studies also reveal that this gendered construction of reproductive time shapes women's understanding of childbearing (Beaujouan and Solaz 2013; Billari et al. 2011; Brown and Patrick 2018) and outlines inequalities between men and women, for example, regarding freedom and choice in couple formation (Pickens and Braun 2018). The narrative of the biological clock produces and reproduces gender inequalities regarding reproductive time that are not only perceived as natural but that also shape asymmetries regarding men and women's positions to negotiate the timing of reproduction against other family, education, and work milestones.

\section{Discussion}

In the present article I have aimed to advance current knowledge on the intersection of time, reproduction, and biopolitics by focusing on the narrative of the biological clock and the 
particular ways in which it shapes women's views and experiences of reproductive time. The findings presented in my article reveal that the biological clock regulates reproductive time by shaping the boundaries and dynamics of female fertility through the clock. By determining reproductive time as quantitative, standardised, linear, and irreversible and by outlining the passing of time through pressure, risk, and burden, the narrative of the biological clock determines when it is possible and desirable to have children and regulates reproduction, gender, and the female life course.

Although the narrative of the biological clock has become prevalent to address the problem of fertility decline, the risks of ageing in the context of late motherhood, and the use of assisted reproductive technologies, too few studies engage in an analysis of the biological clock itself. This oversight means that the social and subjective implications of making sense of the boundaries and dynamics of female fertility through clock time remain largely unexplored. By drawing on theoretical insights on social time (Adam 1995, 2006; Zerubavel 1985) and biopolitics (Foucault 1978, 2003; Rose 2007), I have stressed time as an essential dimension of contemporary biopolitics of reproduction and shed light on the particular ways in which the narrative of the biological clock regulates reproduction, gender, and the female life course.

Clock time is a social construction but it has come to be understood as a natural and inevitable feature of social life (Zerubavel 1985). This understanding becomes evident in the case of the biological clock. Although the female body, fertility, and reproductive cycle have rhythms and temporal dynamics of their own (Adam 1990, 2006), it has become common to address them through the abstract, standardised, and neutral character of clock time. The narrative of the biological clock shapes female fertility according to the clock by embodying it in the nature of the female body. In doing so, this narrative reifies particular ways of understanding and experiencing reproductive time that are socially constructed but are often perceived as given and unalterable. Lived accounts of reproductive time analysed in the present article reveal the extended belief that women have a biological clock that determines when they are capable to have children according to chronological age as well as the fact that their reproductive time is limited, decreases with ageing, and ultimately runs out.

Time is known to be a symbolic means of social control (Adam 1990, 2006; Elias 1989; Zerubavel 1985) and normative structuration of life (Elder Jr 1975; Settersten Jr 2003). By outlining norms regarding when it is possible and desirable for women to have children, the narrative of the biological clock regulates not only reproductive time but also gender roles and the female life course. It is by conflating womanhood, motherhood, and biological childbearing that the biological clock regulates female fertility and controls women insofar as they are living beings. This perspective demonstrates the particular ways in which heteronormativity, gender, and family formation are regulated through ideological narrations of time (Amir 2006).

By providing an empirical and interpretive analysis of the narrative of the biological clock and the ways in which it shapes women's reproductive experiences, my article contributes to advance the understanding of contemporary reproductive time and unravel the social and subjective implications of understanding it through the biological clock. In doing so, my article provides a novel perspective to address prevalent reproductive and fertility trends as well as to make sense of the lived experiences of women who delay childbearing and become mothers at an older age.

\section{Limitations and Future Research Directions}

There are some limitations to the findings presented in the present article. I used a qualitative research design based on a thick description of a small number of cases that enabled gaining an in-depth understanding of the particular ways in which the narrative of the biological clock shapes women's views and experiences of reproductive time. However, the breadth and scope of my study means that attention must be paid when generalising these findings to make sense of views and experiences of reproductive time of Chilean women and women elsewhere. Furthermore, the narrative of the biological clock outlined in my article seems to have extensive similarities with that documented by studies in North America and Western Europe. Future research should aim to continue exploring the universal character of the narrative of the biological clock as well as the particular ways in which the relationship between clock time and female fertility is enacted in specific cultural and social settings.

By focusing on the narrative of the biological clock, the present article has made a unique contribution to understanding prevalent social constructions of reproductive time and how they shape women's choices and practices regarding when to have children. However, this focus meant that the complexities of the relationship between agency and reproductive time were only partially addressed. Future studies should further analyse the relationship between agency and the biological clock as well as describe the strategies through which women manage and negotiate it in timing childbearing, for example, through assisted reproductive technologies (Baldwin et al. 2019; Brown and Patrick 2018; Martin 2010). This focus on the narrative of the biological clock also meant emphasising clock time over other ontologies of time involved in women's childbearing experiences. Future studies should also identify alternative time ontologies that shape reproductive time, like God, nature, and technology (Roberts 2012; Yopo Díaz 2020), and outline the ways in which they conflict and coincide with the normative construction of the 
timing of childbearing as outlined by the narrative of the biological clock.

\section{Practice Implications}

Social constructions of reproductive time are important because they shape the particular ways in which women engage with childbearing and structure life course trajectories related to partnership, family formation, education, and labour. In recent decades, the biological clock has become a prevalent narrative to address the rhythms and boundaries of female fertility. Increasingly, healthcare professionals, policymakers, and the media are using the notion of the biological clock to refer to reproductive time in the context of late childbearing, age-related infertility, and the use of assisted reproductive technologies. The present article stresses the importance of critically addressing the narrative of the biological clock and its implications for women's views and experiences of reproductive time. Scholars and professionals working on fertility and reproduction should examine their preconceptions of reproductive time and become aware that naturalising clock time and reproducing it as a given feature of female fertility contributes to reinforce normative regulations of reproduction, gender, and the female life course. Critically reflecting upon the narrative of the biological clock is an invitation to construct comprehensive approaches to reproductive time that encompass both biological and social fertility; disentangle prevalent conflations among womanhood, motherhood, and biological childbearing; and address prevalent gender inequalities regarding reproductive time. This critical reflection is also an invitation to shift the focus of reproductive time from individual choice to the social conditions that enable and constrain those choices. Such an approach represents an opportunity to craft public initiatives that provide a comprehensive socialisation of reproductive agency and address the social determinants that shape women's choices toward delaying childbearing.

\section{Conclusion}

In the present article I have argued that the biological clock regulates reproductive time by shaping the boundaries and dynamics of female fertility through clock time. Drawing on the analysis of 40 life story interviews of women from Santiago de Chile, it demonstrates that the narrative of the biological clock shapes reproductive time as quantitative, standardised, linear, and irreversible, as well as outlines the passing of time through pressure, risk, and burden. Given that fertility and infertility are considered as a matter of choice and individual responsibility, women are expected to keep track of time, assess reproductive risks, calculate how much time is left for childbearing, and anticipate the future. By outlining a reproductive imperative that conflates womanhood and motherhood, as well as hierarchises biological fertility over social fertility, the narrative of the biological clock naturalises childbearing, reinforces traditional gender norms, and structures the female life course.

Acknowledgements I would like to thank Hande Güzel for her insightful comments on an earlier version of this article. Some of the workshop 'Pensando la maternidad: experiencias y desafíos en Chile, España y Reino Unido' (April 2017) organised by ICSO-UDP and the Institutskolloquium (SS/2019) of the Max-Weber-Institut für Soziologie, University of Heidelberg.

Funding This study received financial support from the National Commission for Scientific and Technological Research (Chile) and the Cambridge Commonwealth, European and International Trust, University of Cambridge (UK). Support for editing this article comes from the Millenium Nucleus for the Study of the Life Course and Vulnerability (MLIV) in Chile.

\section{Compliance with Ethical Standards Statement}

Conflict of Interest The author declares no conflicts of interest.

Ethical Approval This study received clearance from the Ethics Committee of the Department of Sociology, University of Cambridge.

Informed Consent All the participants voluntarily agreed to participate in this study and signed informed consents. No animals were involved in this study.

Open Access This article is licensed under a Creative Commons Attribution 4.0 International License, which permits use, sharing, adaptation, distribution and reproduction in any medium or format, as long as you give appropriate credit to the original author(s) and the source, provide a link to the Creative Commons licence, and indicate if changes were made. The images or other third party material in this article are included in the article's Creative Commons licence, unless indicated otherwise in a credit line to the material. If material is not included in the article's Creative Commons licence and your intended use is not permitted by statutory regulation or exceeds the permitted use, you will need to obtain permission directly from the copyright holder. To view a copy of this licence, visit http://creativecommons.org/licenses/by/4.0/.

\section{References}

Aburto Prieto, F. (2016). Congelando el reloj biológico [freezing the biological clock]. La Segunda. https://digital.lasegunda.com/2016/ 07/09/A/V02VD0CL\#zoom=page-width.

Adam, B. (1990). Time and social theory. Cambridge and Oxford: Polity Press.

Adam, B. (1995). Timewatch. The social analysis of time. Cambridge: Polity Press.

Adam, B. (2006). Time. Cambridge and Malden: Polity Press.

Amir, M. (2006). Bio-temporality and social regulation: The emergence of the biological block. Polygraph: An International Journal of Culture and Politics, 18, 47-72 https://pure.qub.ac.uk/en/ publications/bio-temporality-and-social-regulation-the-emergenceof-the-biolog. 
Atkinson, R. (2002). The life story interview. In J. F. Gubrium \& J. A. Holstein (Eds.), Handbook of interview research. Context and method (pp. 121-140). Thousand Oaks: Sage Publications.

Baldwin, K., Culley, L., Hudson, N., \& Mitchell, H. (2019). Running out of time: Exploring women's motivations for social egg freezing. Journal of Psychosomatic Obstetrics and Gynecology, 40(2), 166173. https://doi.org/10.1080/0167482X.2018.1460352.

Bartlett, A. (2012). Babydaze: Maternal time. Time \& Society, 19(1), 120-132. https://doi.org/10.1177/0961463X09354419.

Beaujouan, E., \& Solaz, A. (2013). Racing against the biological clock? Childbearing and sterility among men and women in second unions in France. European Journal of Population, 29, 39-67. https://doi. org/10.1007/s10680-012-9271-4.

Beets, G., Schippers, J., \& te Velde, E. R. (2011). Introduction. In G. Beets, J. Schippers, \& E. R. te Velde (Eds.), The future of motherhood in western societies. Late fertility and its consequences (pp. 14). New York: Springer.

Billari, F. C., Goisis, A., Liefbroer, A. C., Settersten, R. A., Aassve, A., Hagestad, G., ... Spéder, Z. (2011). Social age deadlines for the childbearing of women and men. Human Reproduction, 26(3), 616-622. https://doi.org/10.1093/humrep/deq360.

Brown, E., \& Patrick, M. (2018). Time, anticipation and the life course: Egg freezing as temporality disentangling romance and reproduction. American Sociological Review, 83(5), 959-982. https://doi. org/10.1177/0003122418796807.

Bryson, V. (2007). Gender and the politics of time. Feminist theory and contemporary debates. Bristol: The Policy Press.

Cerda, R. (2010). Familia y fecundidad [Family and fecundity]. In Encuesta Nacional Bicentenario Universidad Católica - Adimark 2009. Una mirada al alma de Chile. Santiago de Chile: PUC.

Chen, W., \& Landau, R. (2015). First childbirth and motherhood at post natural fertile age: A persistent and intergenerational experience of personal and social anomaly? Social Work in Health Care, 54(1), 16-32. https://doi.org/10.1080/00981389.2014.966880.

Clarke, A. E., Shim, J. K., Mamo, L., Fosket, J. R., \& Fishman, J. R. (2003). Biomedicalization: Technoscientific transformations of health, illness, and U.S. biomedicine. American Sociological Review, 68(2), 161-194. https://doi.org/10.2307/1519765.

Clínica Alemana. (2012). Solteras después de los 30: ¿cuál es la razón? [Singles after 30: what is the reason?] Clínica Alemana. https:// www.clinicaalemana.cl/articulos/detalle/2012/solteras-despues-delos-30-cual-es-la-razon.

Clínica Las Condes. (2017). Fertilidad: Aún falta conciencia sobre el reloj biológico de la mujer [fertility: There is still lack of awareness about the biological clock of women]. Clínica Las Condes. https://www. clinicalascondes.cl/Comunidad-Mujer-Y-Mama/blog-cmm/bloglistado/planificacion/Fertilidad-falta-conciencia-sobre-relojbiologico.

Cooke, A., Mills, T. A., \& Lavender, T. (2010). "Informed and uninformed decision making" - Women's reasoning, experiences and perceptions with regard to advanced maternal age and delaying childbearing: A meta-synthesis. International Journal of Nursing Studies, 47, 1371-1329. https://doi.org/10.1016/j.ijnurstu.2011.07. 013.

Daly, I., \& Bewley, S. (2013). Reproductive ageing and conflicting clocks: King Midas' touch. Reproductive Biomedicine Online, 27, 722-732. https://doi.org/10.1016/j.rbmo.2013.09.012.

Denzin, N. K., \& Lincoln, Y. S. (2005). The discipline and practice of qualitative research. In N. K. Denzin \& Y. S. Lincoln (Eds.), The sage handbook of qualitative research (pp. 1-32). Thousand Oaks: Sage Publications.

Easton, J. A., Confer, J. C., Goetz, C. D., \& Buss, D. M. (2010). Reproduction expediting: Sexual motivations, fantasies, and the ticking biological clock. Personality and Individual Preferences, 49, 516-520. https://doi.org/10.1016/j.paid.2010.05.018.
El Mercurio. (2017). Reloj biológico y maternidad: El aumento en los problemas de fertilidad según la edad de la mujer [Biological clock and motherhood: Increase in fertility problems according to women's age]. El Mercurio. https://www.emol.com/noticias/ Tendencias/2017/11/14/883168/Reloj-biologico-y-maternidad-Elaumento-en-los-problemas-de-fertilidad-segun-la-edad-de-la-mujer. html.

El Mostrador. (2017). Rejuvenecimiento ovárico: la ciencia que retardaría el reloj biológico [ovarian rejuvenation: The science that would delay the biological clock]. El Mostrador. https://www. elmostrador.cl/braga/2017/05/30/rejuvenecimiento-ovarico-laciencia-que-retardaria-el-reloj-biologico/.

Elder Jr., G. H. (1975). Age differentiation and the life course. Annual Review of Sociology, 1, 165-190.

Elias, N. (1989). Sobre el tiempo [Time: An essay]. México, Madrid and Buenos Aires: Fondo de Cultura Económica.

Fabe, M., \& Wikler, N. J. (1979). Up against the clock: Career women speak out on the new choice of motherhood. New York: Random House.

Flick, U. (2009). An introduction to qualitative research (4th ed.). Thousand Oaks: Sage Publications.

Foucault, M. (1986). The history of sexuality (Vol. 3). New York: Pantheon Books.

Foucault, M. (1978). The history of sexuality (Vol. 1). New York: Pantheon Books.

Foucault, M. (2003). Society must be defended. Lectures at the Collège de France, 1975-76. New York: Picador.

Foucault, M. (2008). The birth of biopolitics. Lectures at the Collège de France, 1978-79. New York: Palgrave Macmillan.

Friese, C., Becker, G., \& Nachtigall, R. D. (2006). Rethinking the biological clock: Eleventh-hour moms, miracle moms and meaning of age-related infertility. Social Science and Medicine, 63, 1550-1560. https://doi.org/10.1016/j.socscimed.2006.03.034.

Fuentes, A., Jesam, C., Devoto, L., Angarita, B., Galleguillos, A., Torres, A., ... Mackenna, A. (2010). Postergación de la maternidad en Chile: Una realidad oculta [postponement of motherhood in Chile: A hidden reality]. Revista Médica de Chile, 138, 1240-1245. https:// doi.org/10.4067/S0034-98872010001100005.

Geertz, C. (1973). The interpretation of culture. London: Hutchinson.

Herrera, F. (2011). The building of parental bonds: Adoption and assisted reproduction in Chile. Revista de cercetare si interventie sociala, 32, $25-43$.

Herrera, F., Teitelbom, B., Russo, M., Salas, S. P., \& Zegers Hochschild, F. (2013). Encuesta de opinión pública sobre reproducción humana y usos de tecnología de reproducción asistida en habitantes de Santiago, Chile [Public opinion survey on human reproduction and the uses of assisted reproductive technology among inhabitants of Santiago, Chile]. Revista Médica de Chile, 141, 853-860. https:// doi.org/10.4067/S0034-98872013000700004.

Hirane, J. (2017). ¿Debo congelar óvulos? Revista Paula [Should I freeze eggs?]. Retrieved from https://www.paula.cl/reportajes-yentrevistas/debo-congelar-ovulos/.

Hoffnung, M., \& Williams, M. A. (2013). Balancing act: Career and family during college-educated women's 30 s. Sex Roles, 68, 321334. https://doi.org/10.1007/s11199-012-0248-x.

Hughes, C. (2002). Key concepts in feminist theory and research. London, Thousand Oaks: Sage Publications.

Instituto Nacional de Estadísticas. (2017). Anuario de estadísticas vitales 2017 [yearbook of vital statistics 2017]. Santiago: INE.

Keeney, R. L., \& Vernik, D. A. (2007). Analysis of the biological clock decision. Decision Analysis, 4(3), 114-135. https://doi.org/10.1287/ deca.1070.0094.

Lahad, K. (2012). Singlehood, waiting, and the sociology of time. Sociological Forum, 27(1), 163-186. https://doi.org/10.1111/j. 1573-7861.2011.01306.x. 
Larrañaga, O. (2007). Participación laboral de la mujer en Chile: 1958 2003[Labor participation of women in Chile: 1958-2003]. Santiago de Chile: Departmento de Economía, Universidad de Chile.

Lavender, T., Logan, J., Cooke, A., Lavender, R., \& Mills, T. A. (2015). "Nature makes you blind to the risks": An exploration of women's' views surrounding decisions on the timing of childbearing in contemporary society. Sexual \& Reproductive Health, 6, 157-163. https://doi.org/10.1016/j.srhc.2015.04.006.

Leader, A. (2006). Pregnancy and motherhood: The biological clock. Sexuality, Reproduction \& Menopause, 4(1), 3-6. https://doi.org/ 10.1016/j.sram.2006.03.003.

Leccardi, C. (1996). Rethinking social time: Feminist perspectives. Time \& Society, 5(2), 169-186.

Macintosh, K. L. (2015). Teaching about the biological clock: Agerelated fertility decline and sex education. UCLA Women's Law Journal, 22(1), 1-37 https://escholarship.org/uc/item/5b1147x9.

Manzur, A. (2014). Fácil, de baja complejidad y con buenos resultados [Easy, low complexity and with good results]. Red de Salud UC CHRISTUS. https://www.ucchristus.cl/blog-salud-uc/articulos/ 2014/facil-de-baja-complejidad-y-con-buenos-resultados.

Martin, L. J. (2010). Anticipating infertility. Egg freezing, genetic preservation, and risk. Gender \& Society, 24(4), 526-545. https://doi. org/10.1177/0891243210377172.

Martin, L. J. (2017). Pushing for the perfect time: Social and biological fertility. Women's Studies International Forum, 62, 91-98. https:// doi.org/10.1016/j.wsif.2017.04.004.

Martineau, J. (2015). Time, capitalism and alienation. A socio-historical inquiry into the making of modern time. Boston: Brill.

McAlister, J. F. (2008). Lives of the mind/body: Alarming notes on the tenure and biological clocks. Women's Studies in Communication, 31(2), 218-225. https://doi.org/10.1080/07491409.2008.10162536.

Meier Furst, R. (2018). Vitrificación de óvulos, la nueva revolución femenina [Egg vitrification, the new female revolution]. Clinica IVI Centro de Salud Reproductiva. https://ivinet.cl/notas/la-nuevarevolucion-femenina/.

Miller, T. (2007). Is this what motherhood is all about? Weaving experiences and discourses through transition to first-time motherhood. Gender \& Society, 21(3), 337-358. https://doi.org/10.1177/ 0891243207300561 .

Mohapatra, S. (2014). Using egg freezing to extend the biological clock: Fertility insurance or false hope? Harvard Law and Policy Review, $8(2), 381-411$

Montecino, S. (2018). Madres y huachos. Alegorías del mestizaje chileno [mothers and huachos. Allegories of Chilean mestizaje] (8th ed.). Santiago de Chile: Catalonia.

Moss, J. H., \& Maner, J. K. (2014). The clock is ticking. The sound of a ticking clock speeds up women's attitudes on reproductive timing. Human Nature, 25, 328-341. https://doi.org/10.1007/s12110-0149210-7.

Myers, C. E. C. (2014). Colonizing the (reproductive) future: The discursive construction of ARTS as technologies of self. Frontiers: A Journal of Women Studies, 35(1), 73-106. https://doi.org/10.5250/ fronjwomestud.35.1.0073.

Perrier, M. (2013). No right time: The significance of reproductive timing for younger and older mothers' moralities. The Sociological Review, 61, 69-87. https://doi.org/10.1111/1467-954X.12005.

Pickens, C., \& Braun, V. (2018). "Stroppy bitches who just need to learn how to settle"? Young single women and norms of femininity and heterosexuality. Sex Roles, 79, 431-448. https://doi.org/10.1007/ s11199-017-0881-5.

Pommer, R. (2015). ¿Cuánto saben nuestras mujeres sobre su fertilidad? [how much do our women know about their fertility?]. El Mercurio. https://www.emol.com/noticias/Tendencias/2015/05/17/741923/ Cuanto-saben-nuestras-mujeres-sobre-su-fertilidad.html.

Roberts, E. F. S. (2012). God's laboratory. Assisted reproduction in the Andes. Los Angeles: University of California Press.
Rose, N. (2001). The politics of life itself. Theory, Culture \& Society, 18(6), 1-30. 10.1177\%2F02632760122052020.

Rose, N. (2007). The politics of life itself. Biomedicine, power and subjectivity in the twenty-first century. Oxford: Princeton University Press.

Schreier, M. (2014). Qualitative content analysis. In U. Flick (Ed.), The sage handbook of qualitative data analysis (pp. 170-183). London: Sage Publications.

Settersten Jr., R. A. (2003). Age structuring and the rhythm of the life course. In J. T. Mortimer \& M. J. Shanahan (Eds.), Handbook of the life course (pp. 81-98). New York: Kluwer Academic and Plenum Publishers.

Settersten, R. A., \& Hägestad, G. O. (1996). What's the latest? Cultural age deadlines for family transitions. The Gerontologist, 36(2), 178188. https://doi.org/10.1093/geront/36.2.178.

Settersten Jr., R. A., \& Mayer, K. U. (1997). The measurement of age, age structuring and the life course. Annual Review of Sociology, 23, 233-261. https://doi.org/10.1146/annurev.soc.23.1.233.

Sevón, E. (2005). Timing motherhood: Experiencing and narrating the choice to become a mother. Feminism \& Psychology, 15(4), 461482. $10.1177 \% 2 \mathrm{~F} 0959-353505057619$.

Strauss, A., \& Corbin, J. (1998). Basics of qualitative research: Techniques and procedures for developing grounded theory. Thousand Oaks: Sage Publications.

Thacker, P. D. (2004). Biological clock ticks for men, too. Journal of the American Medical Association, 291(14), 1683-1685. https://doi. org/10.1001/jama.291.14.1683.

The World Bank. (2019). The little data book on gender 2019. Washington, D.C: The World Bank.

Valdés, X. (2007). Notas sobre la metamorfosis de la familia en Chile [notes on the metamorphosis of the family in Chile]. Santiago de Chile: CEPAL and UNFPA.

Velarde, M. (2016). Reproducción asistida [assisted reproduction]. In C. Dides \& C. Fernández (Eds.), Primer informe salud sexual, salud reproductiva y derechos humanos en Chile (pp. 99-110). Santiago de Chile: Miles Chile.

Waldby, C., \& Cooper, M. (2008). The biopolitics of reproduction. Australian Feminist Studies, 23(55), 57-73. https://doi.org/10. 1080/08164640701816223.

Wagner, M., Huinink, J., \& Liefbroer, A. C. (2019). Running out of time? Understanding the consequences of the biological clock for the dynamics of fertility intentions and union formation. Demographic Research, 40, 1-26. https://doi.org/10.4054/DemRes.2019.40.1.

Whittaker, A. (2015). Technology, biopolitics, rationalities and choices: Recent studies of reproduction. Medical Anthropology, 34(3), 259273. https://doi.org/10.1080/01459740.2015.1019066.

Wyndham, N., Marin Figueria, P. G., \& Patrizio, P. (2012). A persistent misperception: Assisted reproductive technology can reverse the "aged biological clock". Fertility and Sterility, 97(5), 1044-1047. https://doi.org/10.1016/j.fertnstert.2012.02.015.

Yopo Díaz, M. (2018a). Enacting motherhood: Time and social change in Chile. Journal of Gender Studies, 27(4), 411-427. https://doi.org/ 10.1080/09589236.2016.1223619.

Yopo Díaz, M. (2018b). Revisiting individualization: The transition to marriage and motherhood in Chile. Current Sociology, 66(5), 748768. https://doi.org/10.1177/0011392117737819.

Yopo Díaz, M. (2020). Making the right time: The transition to motherhood in contemporary Chile (doctoral thesis, University of Cambridge, Cambridge, United Kingdom). https://doi.org/10. 17863/CAM.50351

Zerubavel, E. (1985). Hidden rhythms. Schedules and calendars in social life. Los Angeles: University of California Press.

Publisher's Note Springer Nature remains neutral with regard to jurisdictional claims in published maps and institutional affiliations. 